UDC 37-042.4:004

Tetiana V. Fisenko

$\mathrm{PhD}$ in Social Communications, Associate Professor at the Department of Publishing and Editing National Technical University of Ukraine "Igor Sikorsky Kyiv Politechnic Institute", Kyiv, Ukraine ORCID ID 0000-0003-1837-0117

tfisenko@gmail.com

Olviia O. Husak

$\mathrm{PhD}$ in Social Communications, Associate Professor at the Department of Publishing and Editing National Technical University of Ukraine "Igor Sikorsky Kyiv Politechnic Institute", Kyiv, Ukraine ORCID ID 0000-0002-7255-6492

olviya.g@gmail.com

Olha V. Trishchuk

Professor, Doctor of Social Communications, Professor at the Department of Publishing and Editing National Technical University of Ukraine "Igor Sikorsky Kyiv Polytechnic Institute", Kyiv, Ukraine ORCID ID 0000-0002-4009-8749

triov@ukr.net

\title{
THE USE OF WEB-SERVICES AND APPLICATIONS IN FORMING MEDIA LITERACY OF FUTURE JOURNALISTS
}

\begin{abstract}
This research paper exposes functional features of the existing applications that are worth including in the journalism educational programs. Such inclusion will pursue the purpose of teaching media literacy to junior university students (namely, freshmen and sophomores) along with designing the Google browser AntiSepar Application. The application has been tested in practice by students majoring in journalism studies. The paper also sets the preconditions of the application's technical tasks that were elaborated within the framework of the research project "Tools of asymmetric response to hybrid aggression in the humanitarian field" carried out at the Department of Publishing and Editing (Publishing and Printing Institute) at the National Technical University of Ukraine "Igor Sikorsky Kyiv Polytechnic Institute", Kyiv, Ukraine. The designed questionnaire completed by university trainees has confirmed the efficacy of the developed system which can be a helpful tool for analyzing media content on a variety of topics (100 respondents filled out a survey).

Additionally, during distant group discussions and practice sessions, senior journalism students were offered a more sophisticated algorithm of information processing worked out with the help of the automated systems of wavelet data analysis. A few media-cases were analyzed to work out the main schemes of information processing through InfoStream and Attack Index services. The second part of the research contains the results of the survey, conducted among the Master's degree students (64 students were interviewed).

Finally, the authors concluded that the application of these tools makes it possible for media specialists to monitor news streams and their interconnections as well as the sources of information dissemination with ease and efficacy.
\end{abstract}

Keywords: web-service; journalism; media literacy; mobile application; education.

\section{INTRODUCTION}

The problem statement. In recent years, information wars, the necessity to reveal manipulative, false information and propagandistic content, media's influences on public opinion alongside the development of new informational technologies of data processing have caused the emergence of tools to detect harmful media content. The issue is especially topical in terms of psychological techniques used in contemporary information warfare. Fostering professional competencies with journalism students requires the skills of using popular and specialized web-resources to examine the information environments. The implementation of 
the research results is supposed to have beneficial effects on their future professional activity. Journalism students' integral competence, characterized by the uncertainty of conditions for effective communication, includes the accomplishment of complex specific tasks and problem solutions in the social communication sphere. Such skills are determined by theoretical provisions and methods of social communication studies.

The examined toolkits provide the students with techniques enhancing the skills in information environment diagnosis. First-year trainees are advised to resort to the most popular, quite simple web-services and applications aimed at the formation of future journalists' creative thinking and media literacy. Meanwhile, senior students can make effective use of more sophisticated tools such as monitoring techniques, content-analysis techniques, and the techniques of reputation audit.

Analysis of recent studies and publications. Media education and media literacy have attracted much attention of Ukrainian and foreign scholars.

The international background of the research is presented by the studies of J. Kahne et al. [1], T. Valtonen et al. [2], T. Cherner and K. Curry [3], H. Schmidt [4], E. Schilder et al. [5], P. Rasi et al. [6].

A wide range of issues related to our study have been raised in the scientific paper "Media Literacy Education in the Age of Machine Learning" [2]. The authors pay special attention to the various educational activities aimed at forming students' competencies in media literacy. Besides, researchers focus on specific pedagogical techniques that are reflected in the curricula of relevant courses and have been tested in several educational institutions.

The research papers "Media Literacy Education for All Ages" [6] and "Media Literacy Education from Kindergarten to College: A Comparison of How Media Literacy Is Addressed across the Educational System" [4] emphasize the need to work on media literacy with different age groups. However, H. Schmidt noted that educators had reported addressing media literacy competencies most frequently within higher education.

The theoretical background of media education, as well as media's influence on the public consciousness, is considered by V. Rizun [7]. Meanwhile, Kazakh scientists A. Begalinov et al. [8], as well as Ukrainian researcher L. Naidionova [9] discuss pedagogical implications of information technologies in media literacy education.

Particularly, the article "Digitalization of Higher Education and Professional Development of Educators: Technologies and New Opportunities" [10] highlights conceptual considerations of implementing digital technologies in the higher education curriculum. Among the topical questions under study is the necessity for the instructors' further professional development and the technologies that will facilitate this process.

The tendencies in media education and media culture in the present-day information society are studied by $\mathrm{O}$. Konevshchynska [11]. The scholar offers a survey of recent research publications dealing with the importance of media education and its role in a wider educational paradigm. The author also dwells upon media awareness enhancement of educational institutions.

Another research vector is adopted by Russian researchers Y. Klyuev et al. [12]. The researchers outline general perspectives in journalists' professional training connected with up-to-date digital technologies. Besides, the authors examine the practical skills students gain in the course of study. At the same time, the paper fails to provide specific tools and instruments for conducting media investigations.

Research articles and monographs focusing on media literacy in the hybrid war environment have recently been published by S. Fiialka [13], [14], and O. Husak [15], T. Fisenko [16], and L. Smola et al. [17]. The papers specify the findings of the applied research project "Tools of asymmetric response to hybrid aggression in the humanitarian field" carried 
out at the National Technical University of Ukraine "Igor Sikorsky Kyiv Polytechnic Institute".

However, little research has been undertaken to study the role of toolkits and webservices used for manipulative and fake content detection in the course of journalists' professional training.

The research goal is to report the theoretical and empirical research results of using applications and web-services in media literacy education of university journalism students. The research process included the following tasks: specialized application development (including preliminary market research, content-analytical studies to form a technical task), and working out convenient algorithms for media specialists' professional work with specialized web-services.

\section{RESEARCH METHODS}

The research methods used in this study are a) general theoretical methods, namely analysis, synthesis, and comparison. These methods were applied to analyze contemporary technologies of detecting the manipulative content and their appropriateness in the education process; b) the methods of generalizing and systematizing data were used to define the students' competencies and skills that are essential for media literacy enhancement; c) content-analysis and statistical methods appeared to be effective in an in-depth examination of internet media texts, in identification of propaganda and separatist content markers, in designing the software to be used for educational purposes; d) a questionnaire-based survey was undertaken to conduct a paper and pencil interview of students (a total of 164 respondents were questioned) as for convenience and efficacy of the newly designed AntiSepar application and other specialized web-services, such as InfoStream and Attack Index; e) wavelet analysis was used to describe the graphs of information wave oscillations and to define the sources of information in terms of their natural or artificial origin, and to point to the oscillation deviations from the norm. The wavelet analysis served as a pattern of detecting artificially generated information streams which may be interpreted as information threats; f) finally, the trial testing of mobile applications and web-services during university practice sessions were performed and analyzed using the case-study method.

\section{THE RESULTS AND DISCUSSION}

The most popular tools of general practice that can be easily used even by inexperienced users, such as freshmen or sophomores, are browsers (Chrome, Mozilla Firefox), social media chat-bots (Telegram and Facebook Messenger), and mobile applications. The online-services effectively function to foster the media literacy of their users. If one browses the 'fake news' search query at the play markets from Chrome, App Store, or Play Market, the search results would include dozens of entries. According to the users' opinions, Fake News Detector, Surf Safe, FakerFact, Fake news debunker, Fake News Spotter Lite, NewsCracker, FakesKiller enjoy the greatest popularity. They operate in different ways: some of them mark fake news based on users' responses; others rely on artificial intelligence algorithms or the combination of several methods, such as linguistic or fact analysis. Despite the mentioned differences, the didactic potential of these systems is similar, since all of them can instruct journalism students as to the basic means of information checks for credibility and authenticity.

To illustrate the point, let us consider the Fake News Detector. The application is trained to analyze internet page contents and reveal false or potentially manipulative 
information. When such content is detected, the word "FAKE" appears next to the news' headline. A similar indication emerges next to the reference linking to an unreliable source. Printed in orange, the markers "CLICKBAIT" or "PROBABLY FAKE" certify potentially manipulative stories.

The principles of machine learning and statistical analysis used to identify fake data lay the groundwork for NewsCracker. The plugin assesses the information and ranks its credibility on a scale from 0 to 10 . While checking the articles' probable inaccuracy or bias, the system considers three major parameters: accuracy, objectivity, and the headline's neutrality. Approaching the content from this perspective helps students to master professional comprehension of information. This skill will enable media workers to look for further use of the analyzed data.

In some cases, plugins are designed to check the reliability of video and audio content. For instance, Surf Safe software classifies the images retrieved from the news posts into "secure", "non-secure", and "the ones that the audience should beware of". Surf Safe also points to all the sources that disseminated particular images for users to compare the given video content with the authentic one.

It is necessary to state that the plugins, discussed in this paper, are available for English language settings. That is why Ukrainian students' research activity is very much limited to foreign sources. Nevertheless, some similar applications and plugins process Ukrainian and Russian content. Namely, back in December 2019, the editorial board of Texty.org.ua presented the newly created application "Feikohryz" (literally meaning "fake news gnawer"). "Feikohryz" as an artificial intelligence tool notifies its users of manipulation or misinformation in the news content. The application works as a plugin for Chrome and Mozilla Firefox and as a chat-bot for Telegram.

According to "Feikohryz" developers, the tool is based on the neural network trained on 7000 information entries. The news was double-checked and marked by journalists. After that, another set of 2000 news pieces expanded the database following the machine editing. Further on, the data was manually verified and the classifier's errors were corrected. Thus, when a user installs this extension and visits the website frequently publishing manipulative materials or the ones that do not conform to journalism standards, he/she will be notified of it. In case "Feikohryz" receives a link to a Telegram publication, it will advise the user of probable fakes or journalist ethics violations.

In each processed text, the application marks its language units (words) and punctuation marks and lemmatizes them for thematic modeling. The texts are then analyzed by a manipulative news classifier (in Russian and Ukrainian based on ULMFiT, programmed in Pytorch / fast.ai) to estimate probable emotional manipulation and/or erroneous argumentation. Selected manipulative news, on average 3000 items per week, is divided into topic groups with the help of an automated theme modeling. The users themselves can supplement the artificial intelligence marking the news as fake. Thus, students become involved in defining the content's credibility. The developers claim the application's 95\% accuracy.

The Department of Publishing and Editing (Publishing and Printing Institute) at National Technical University of Ukraine "Igor Sikorsky Kyiv Polytechnic Institute" has developed the Chrome browser AntiSepar application as a part of the research project "Tools of asymmetric response to hybrid aggression in the humanitarian field". The system is capable of detecting propaganda and separatist content in the news web-sites both in the course of casual surfing the net and in the educational process. The main objective of practicing the application is to enhance media literacy and critical thinking of junior students' majoring in journalistic studies. Since youth is a very information-sensitive age group, young people have to be aware of the probable manipulative implications in present-day media messages. Thus, 
automated electronic tools for detecting a hidden fake content may come in handy at university in-service lessons within the media education curriculum.

So, to foster students' critical thinking and media literacy skills, we have designed a Chrome application that can be used for academic purposes. We have conducted the content analysis and other investigative procedures of texts with harmful or illegal content retrieved from an average of 140 websites. The research made it possible to single out the criteria according to which separatist and propaganda information can be detected, so its viewing can be restricted. The criteria for such sites are the following:

1. The sites are on the web-resources list that the Ukrainian Ministry of Informational Policy has officially acknowledged as the ones probably containing the information prohibited for dissemination (for example, calls for a violent overthrow of the constitutional line-up, seizure of the state power, etc.) [13]. Web pages of the so-called "official institutions and bodies" of the ORDLO region (Ukrainian and Russian acronym standing for certain areas of the Donetsk and Luhansk regions), their controlled media, news agencies, press services, etc. are among such sites.

2. The sites that contain active links to the resources mentioned in the previous paragraph. Only the links occurring in the main texts were taken into account, since subscribers' commentaries do not reflect the editorial policy.

3. The sites' texts have the following language (lexical) markers of separatism: "Ukrainian men of arms", "UAF (Ukrainian armed forces) shed bombs onto...", "The National Guard's / Ukrainian armed guerillas", "Ukrainian executioners", "Kyiv junta", "Ukrainian Nazi/fascists", "Donetsk / Luhansk People's Republic heroes" etc. Sometimes, these words, acronyms, and abbreviations can also be found in the pro-Ukrainian electronic media, mostly in citations illustrating the speakers' negative attitudes towards the listed bodies, people, or phenomena. That is why if the application is run on propaganda and separatist resources, additional search parameters have to be applied. For example, in the search inquiry such words or expressions as "the so-called terrorist", "self-proclaimed" should be typed without quotation marks.

4. The web-site texts contain pejorative neologisms. Svitlana Fiialka, a media researcher, has conducted thorough scrutiny of separatist Internet resources and singled out the following Ukrainian and Russian new words of an insulting nature: a) neologisms denoting hostile attitudes towards 2013-2014 "Revolution of dignity" in Ukraine; b) Russian and Ukrainian neologisms denoting insulting pro-Russian separatists' bias towards Ukraine, its governments, population, media, and non-governmental organization; c) neologisms derived from the name of Stepan Bandera, early and middle 20th-century Ukrainian nationalists' leader [13, pp. 18-19]. G. Pryschepa in a similar study from the perspective of linguistics confirmed these patterns using the method of content analysis of the Ukrainian media [19].

5. The sites contain video content or links to the YouTube bloggers' and organizations' channels that share separatist and propaganda materials: A. Shariy, MOUNT SHOW (D. Kaigermazov), Ye. Kovalenko, A. Vasserman, Yu. Kotenok, "In fact", N. Poklonskaya, "Khrustalik TV", The Press Service of People's Militia of Donetsk People's Republic, D. Puchkov, I. Okhlobystin, “Anna News", “Antiwar", M. Ravreba, "ZVEZDA TV channel”, "BesogonTV", E. Limonov, etc.

The service runs according to the following algorithm:

- The application processes the site being currently viewed by a user. In case the page meets the above-enlisted criteria, the service generates a pop-up window with a warning notice: "Warning! This site may contain propaganda and separatist content or a link to such sites". The language of the issued notification is selected according to the browser settings of 
particular users. Currently, the service is available for Ukrainian, Russian, and Englishspeaking users.

- The warning window suggests two alternatives - "Leave the site" or "Continue to the site". Additionally, the service may offer the user another option "Do not show the warning notice anymore", which is available just once during a single Internet session. Meanwhile, access to such-like sites will be forbidden for trainee-students.

The system's interactive components are based on the up-to-date programs' standardized graphic interface.

At present, the AntiSepar application is being tested. After the testing is accomplished, the service will be introduced into the university curriculum. It will surely help to teach media security and critical thinking to journalism students, as it will minimize the harmful influence of separatist content on the youth.

Another stage of our research was carried out through questioning the students, the application's users, about the service's efficacy in detecting malicious information.

The study aimed to define AntiSepar's expediency and convenience. The tasks to be accomplished in the research were:

- to determine the need for implementing the software detecting the separatist and propaganda content in higher education programs;

- to estimate how expedient and effective the application is; to detect the applications' operational errors;

- to evaluate the prospects of using the service in spotting separatist and propaganda resources on the Internet.

The methodology included completing a questionnaire (10 questions). In particular, the respondents were asked to test the application first, and then to answer the following questions: how often the students happened to visit the sites with the separatist content before installing the tool; what kind of response was evoked by such sites; how the students were directed to suchlike web-pages; how often users received warning notifications of propaganda and separatist information from the AntiSepar App; what actions were undertaken in response to the received notifications; if there were any separatist or propaganda sites not processed or erroneously processed by AntiSepar; how advantageous the application is; if the students plan to use the application further on.

The survey was conducted among first- and second-year students of the National Technical University of Ukraine "Igor Sikorsky Kyiv Polytechnic Institute" (100 respondents).

The research was carried out on 2-6 May 2020.

Table 1

\section{Respondents' answers to the question "How often have you encountered separatist/propaganda sites?"}

\begin{tabular}{|l|c|}
\hline \multicolumn{1}{|c|}{ Answer options } & Percentage of respondents \\
\hline Often & $24 \%$ \\
\hline Occasionally & $31 \%$ \\
\hline Hardly ever & $28 \%$ \\
\hline Never & $17 \%$ \\
\hline
\end{tabular}

The summarized research findings are as follows:

1. $24 \%$ of respondents had often visited separatist or propaganda sites before they installed AntiSepar App. In the majority of cases, these sites were randomly surfed. One-third of the participants $(31 \%)$ visited such web-pages from time to time and $17 \%$ never visited them. (Table 1). 
2. Separatist/propaganda sites have evoked mixed feelings with the respondents. Thus, $11 \%$ of the participants experienced negative emotions (fear, discomfort, perplexity). These feelings may be caused by psychological and cognitive immaturity that makes people unprotected from the destructive outer influence. A quarter of respondents demonstrated their neutral attitude to the information from the visited sites. As a result, such participants may fail to critically assess the content's harmful impact. However, the majority (57\%) were fully aware of the informational veracity; thus, negative emotions with these students were reduced to a minimum.

3. After installing the application, $32 \%$ of the respondents received several warning notifications about the separatist/propaganda content, while $43 \%$ got the notification quite rarely. Following the notices, the users ignored such Internet sites as a rule; only $7 \%$ of students proceeded to browse the resources.

4. A large majority of the respondents $(78 \%)$ did not notice any functional errors with the application. The separatist/propaganda content was accurately identified; no misidentification occurred; the warning notifications were appropriate. Only a few participants $(3 \%)$ report the erroneous detection of information of doubtful credibility in the sites that were not marked as separatist or propaganda ones.

5. All the respondents consider the AntiSepar App to be a helpful and effective tool (the average efficiency point is 4.33 out of 5). The application does not require any additional adjustments.

6. $64 \%$ of those questioned plan to use the application in the future. The intention testifies to the service's relevance. The number of students who are uncertain about using the application further on is $17 \%$, while $19 \%$ will not make any use of the tool in the future at all (Table 2).

Table 2

\section{Respondents' answers to the question 'Do you intend to use the AntiSepar application in the future?"}

\begin{tabular}{|l|c|}
\hline \multicolumn{1}{|c|}{ Answer options } & \multicolumn{1}{|c|}{$\begin{array}{c}\text { Percentage of } \\
\text { respondents }\end{array}$} \\
\hline I intend to use the application & $64 \%$ \\
\hline I have not made my mind yet & $17 \%$ \\
\hline I have no intention to use the application & $19 \%$ \\
\hline
\end{tabular}

Generally speaking, the obtained results show that there is a necessity to implement the described applications in higher education institutions as well as outside the classrooms (for media-illiterate or non-experienced Internet users). The application is highly effective; it meets the users' needs. Thus, the service would be in great demand among people unwilling to have uncontrolled access to separatist/propaganda content on the net.

Senior students majoring in Journalism Studies got acquainted with specialized webservices (InfoStream and Attack Index) in the course of their practical training. Academic requirements concerning the skills and abilities of senior students are high enough and encompass not only basic media literacy knowledge (identification of information sources, discriminating between verified and fake data, etc.) but also the aptness to carry out independent research and analytical work. At the end of the course study, the trainees are supposed to learn how to design project documentation and conceptualize the accomplished projects; to justify the preliminary project decisions; to apply methods of media products control; to issue radio and TV media products; to select channels and tools of public communication as well as means of manufacturing and marketing media products, etc. Mastering these competencies requires data processing, its transformation, and further transmission apart from a simple data selection. Journalism students are supposed to follow 
current tendencies and regularities of information processes in a variety of social activities. They can refer to specialized web-services and tools that analyze a great amount of data following the search engines' algorithms. Also, the services are trained to issue numerical statistic indices and present wavelet analytical prognostic graphs. Such tools are used in the course of teaching "Agency Journalism", "Crisis Communication" and "Advertising Marketing" to third- and fifth-year students.

The InfoStream system focuses on monitoring news stories. It can analyze the quantitative dissemination indices of information on various topics. The service developers declare the following set of tasks InfoStream can perform: current events analysis; forecast, assessment, and detection of potentially unreliable sources; revealing the trends of the consumers' market development; determining the spheres that are under the influence of crisis or conflict situations; analysis of competitors', partners' and customers' activity. InfoStream updates its databases effectively every 15 minutes, compiles semantic chains, and establishes interconnections between separate matters.

Journalism students, taking the subjects related to media commercials and public relations spheres, praised InfoStream's function of defining the so-called daily/weekly/ monthly or another time frame "news agenda". The system tracks several replications of the content, notwithstanding language changes and other alterations, and determines the main entries. The user is welcomed to view all the sources which disseminated particular news pieces.

To test this function of the service, third-year students at "Agency Journalism" classes were set a complex assignment to monitor the events that occurred during a couple of previous days (the dates 18-22 May 2020 were selected) and to single out the main ones. The trainees had to use the InfoStream system. The practical group session was held distantly on the Zoom online-platform. The lesson's outcomes include a list of the most popular news stories, as shown in Table 3.

Table 3

18 May 2020 Ukrainian media major news stories (tracked by InfoStream web-service)

\begin{tabular}{|l|c|l|}
\hline \multicolumn{1}{|c|}{ News headline } & Index of mentions & \multicolumn{1}{|c|}{ Thematic area } \\
\hline $\begin{array}{l}\text { Girkin gave an interview to Gordon. The interview will be } \\
\text { attached to the investigative materials against Russia }\end{array}$ & 186 & Politics \\
\hline Quarantine relief after 22 May & 59 & Medicine, social sphere \\
\hline China closes a province after the coronavirus outbreak & 31 & Medicine \\
\hline $\begin{array}{l}\text { Ukraine opens the sky alongside the European countries } \\
\text { on 15 June, but not without conditions }\end{array}$ & 19 & Transportation, tourism \\
\hline $\begin{array}{l}\text { Two new coronavirus cases confirmed in Kamianets- } \\
\text { Podilskyi, Khmelnytskyi region }\end{array}$ & 17 & Medicine \\
\hline $\begin{array}{l}\text { A two-month record: Italy claims COVID-19 daily victims } \\
\text { fell lower than 100 }\end{array}$ & 15 & Medicine \\
\hline
\end{tabular}

As overall monitoring suggests, Ukrainians tend to prioritize domestic and foreign politics and medicine (regarding the COVID-19 pandemic).

At the next stage of the study, students had to follow public responses to the subtopics with the help of the service's rubricating function. Selecting the topic of "Politics" first, the service will then enlist indices and reference links of the news using the "Stories" function.

So, the first news in the "Medicine" rubric deals with a quarantine relief: "The president approved of public transportation resuming its work starting on 22 May" (85 replications), while the scandalous Gordon's interview ("SBU is called to open a criminal case against Gordon. His central office is being picketed") is replicated only 68 times.

The top three "Medicine" news are "COVID-19 in the Ukrainian armed forces: the number of confirmed cases among militants" (70 replications), "The American company 
claims successful test of a coronavirus vaccine" (65 replications), "The second coronavirus wave is likely to be worse than the first one, WHO informs" (60 replications). The story "Spain will begin summer tourist-free" (99 replications) is the top news in the "Tourism" rubric.

Both automated news tracking and manual news monitoring rank two news pieces from the "Politics" rubric equally. Their headlines are: "The president approved of public transportation resuming its work starting on 22 May" and "SBU is called to open a criminal case against Gordon. His central office is being picketed". The electronic system determines "quarantine" as the key-word for the first news entry and the proper name "Gordon" for the second one. To define the origin of the information streams (natural or artificial), the Attack Index system was applied. It automatically diagnoses the information space according to several parameters and discovers the sources that break in the streams. Such intrusions are indicated by the wave graphs.

For example, the Attack Index system assigned the "quarantine" threat in March-April 2020 a score of 3 out of 10 (which is a low threat level). After that, wavelet-analysis techniques were applied to compare two graphs - the graph constructed by the Attack Index system and the one that describes the natural information traffic, i.e. non-artificial streams. The natural processes are presented by the Gaussian Curve, a reversed bell-shaped graph [20, pp. 109-114] (Figure 1). In case the information campaign is intentionally planned (artificial), the normal curve turns into a "Mexican hat wavelet" [21] (Figure 2).

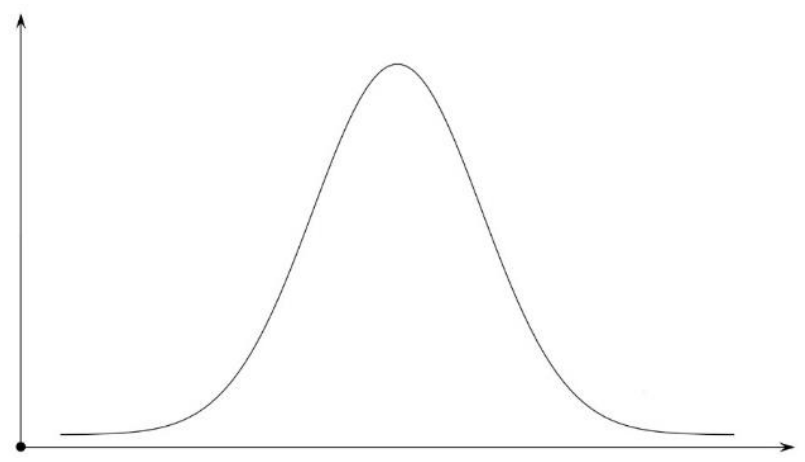

Figure 1. Gauss curve demonstrating the normal distribution of informational flow
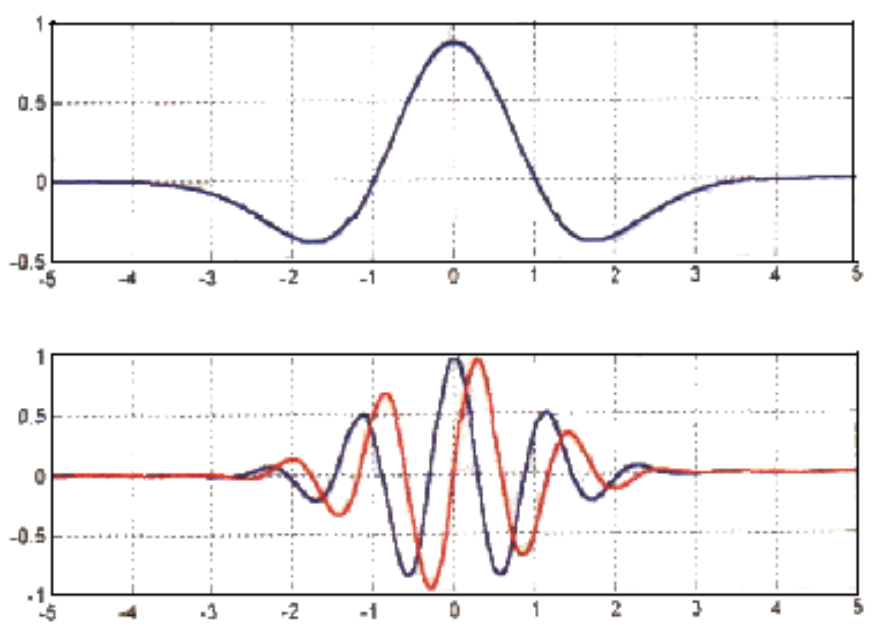

Figure 2. "Mexican hat" - the curve corresponding to the graphic of a planned information campaign flow 
The Attack Index graph constructed on request of "quarantine" for March-May 2020 is shown in Figure 3. An even distribution of the news quantity at the rise and fall of the wave curve proves the natural origin of the information traffic. Artificial intelligence defines the information threat level as low.

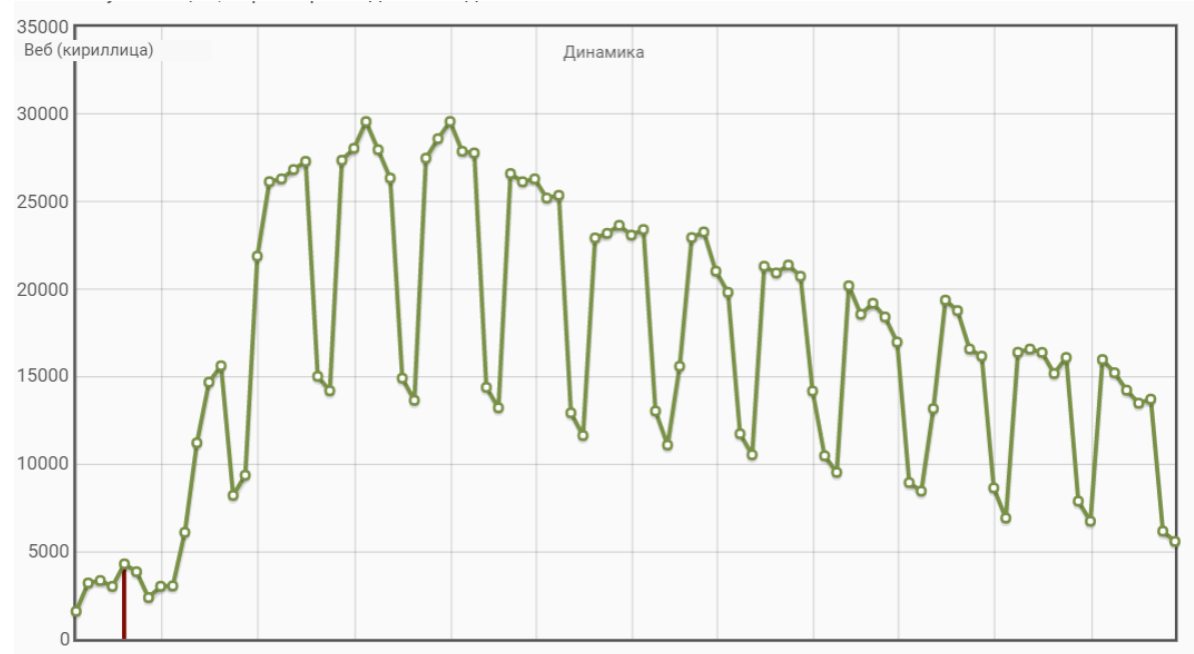

Figure 3. Dynamics of news quantity with the key-word "quarantine”, March-May 2020

Further research findings prove the natural origin of the information streams that media generated on this topic. Having studied the sources of the news stories, we concluded that the system marked them as artificial due to the absence of relation to "quarantine" or "medicine" topic areas. Neither do they deal with the imposed pandemic restrictions.

Another news selection within March-May 2020 time frame concerns a famous Ukrainian journalist Dmytro Gordon. In the course of an in-class group discussion, the students concluded that if the stories contain the journalist's surname as a key-word, it is logical to draw a name-based dynamic graph. Since Gordon's violation of journalistic ethics and his expression of non-patriotic views are not limited to a particular period unlike the "quarantine" topic, we decided to expand the period of search requests. To define the most appropriate period, the words "Gordon" and "separatism" were browsed in the Google search engine. The top search result of recent years was the episode from the "Evening Prime" program broadcast on the YouTube platform of $112 \mathrm{TV}$ channel. The episode was shown on 23 December 2016 under the title "The Kremlin's shaking hand, or Gordon, the separatist". Thus, this date became a starting point of the search.

The largest burst in the information activity was observed on 19 May 2020 (68 points out of 100) as illustrated in Figure 4.

Let us have a closer look at the quantity of media post replications. The Attack Index must define the date of the irregular information activity. The system can specify particular dates of the informational snapshots by clicking on the graph. But it was not D. Gordon's interviews with Nataliia Poklonska (a former Crimean prosecutor accused of separatism; a deputy of the State Duma of Russian Federation) and Igor Girkin (the former so-called "chief army commander of Donetsk People's Republic", who is on the international wanted list as an accomplice to an MH17 airplane crash in the sky over the Donbass area) that attracted the public attention. The most widely read publication (911 replications) was a scandalous news story "Gordon: the interviews with Poklonskaya and Girkin conducted 'in alliance' with security services". While disseminating the publication, the media abundantly quotes Dmytro Gordon, who asserts that the flashcard with the recorded interviews has been directed to the 
Hague Tribunal. The recordings will serve as evidence at the court hearings on the Crimea case and the war outbreak in the Donbass.

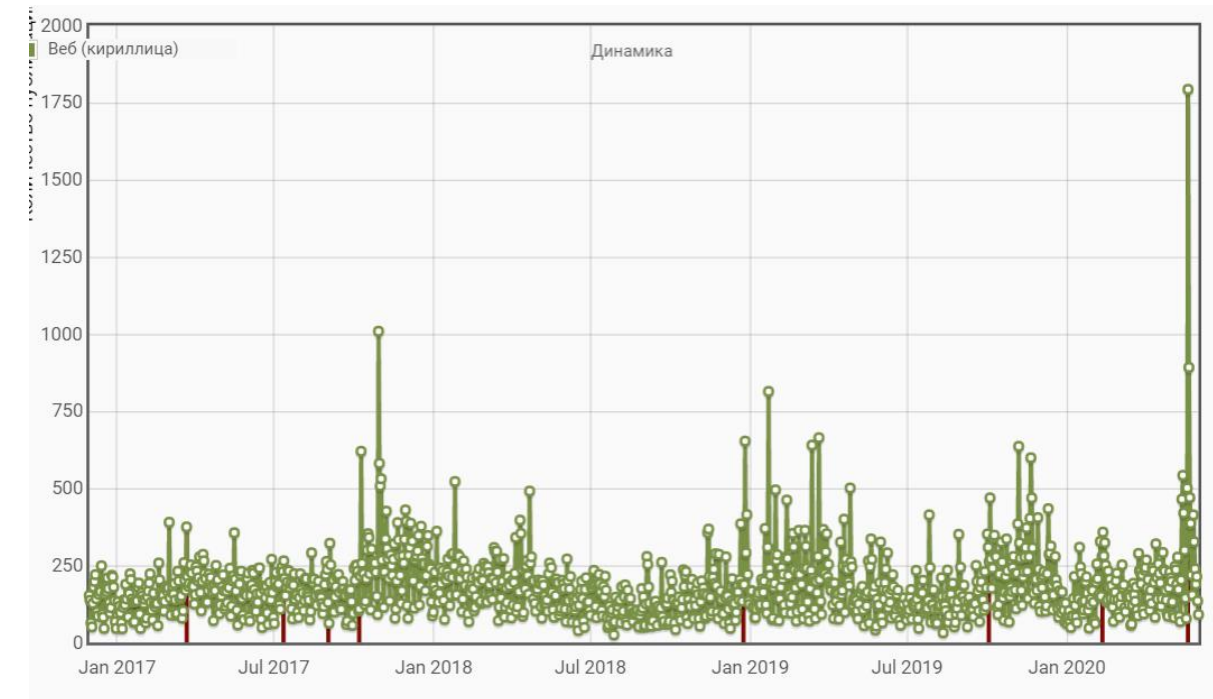

Fig. 4. Dynamics of news quantity with the key-word "Gordon”, December 2016-May 2020

Remarkably, if we consider the quantity list of sources that fall on the peak points, we can presume that the main content was generated by the media belonging to D. Gordon himself. The research findings point towards an a-typical phenomenon when the content generator disseminates and replicates the data itself.

We may, thus, conclude that the algorithm of media content analysis would be of great importance in journalists' professional activity. It was attested during university practice sessions of the "Agency Journalism" course. The moves of the algorithm are as follows: defining the topic agenda for a definite period, a quantitative ranking of topics on the InfoStream basis; singling out the key-words for 2 or 3 top thematic areas (1 key-word per each topic); InfoStream news monitoring and automated graph drawing to illustrate the information waves and their origins (natural or artificial). Also, students are to be acquainted with the wavelet analysis that contributes to a better understanding of how the system works. The journalism students, thus, are taught to notice and identify the news trends, define reliable sources, discriminate between true information and the data artificially "thrown" into the informational space.

Moreover, public relations and commercials specialists will find such media content monitoring systems very beneficial. They can come in handy for running reputation audits of business companies, pointing out strong and weak points in business functioning, and designing appropriate promotional and PR strategies.

Another research method, that of a case study, turned out to be rather effective. It was used by third- and fifth-year students fulfilling practical assignments in "Advertising Marketing" and "Crisis Communications" courses. The trainees had to analyze media news posts dedicated to Roshen Confectionary Corporation published the previous year. The news stories were monitored for key-words and issues influencing the corporation's reputation.

The Attack Index assigned the threat score of 5 (medium intensity). The artificial intelligence computations show that the activity of network resources requires close attention and feedback through informational newsbreaks of their own (Figure 5). 


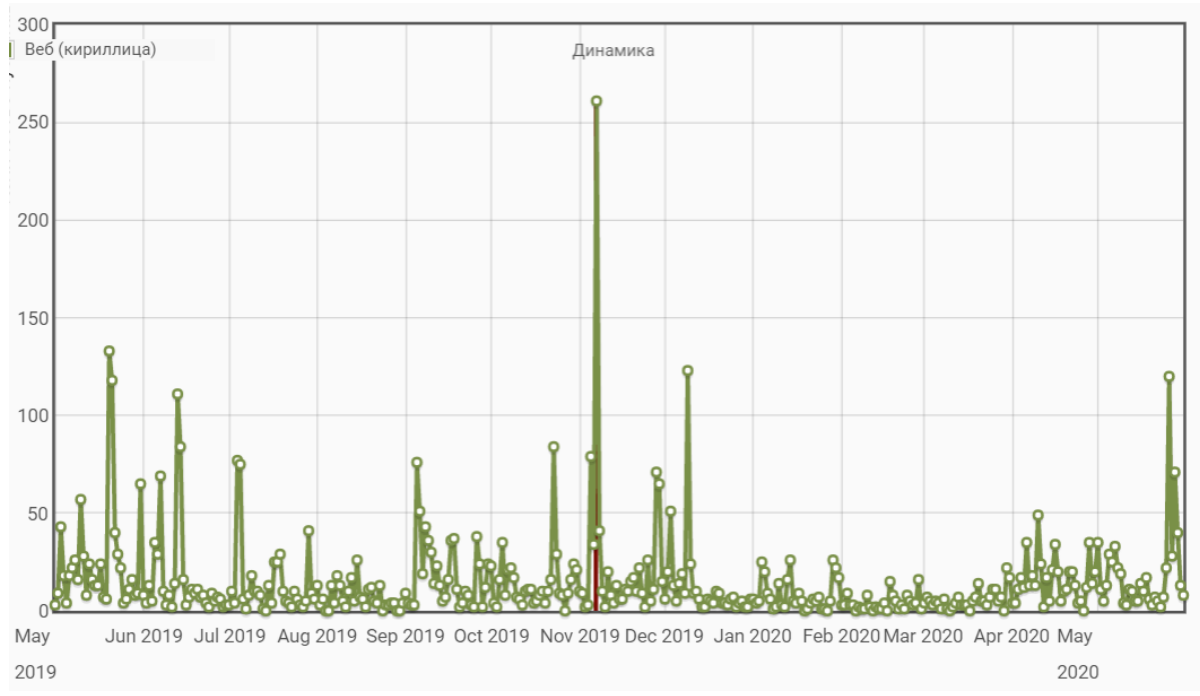

Fig. 5. Dynamics of news quantity with the key-word "Roshen”, May 2019-May 2020

The intensity of the information space is caused either by the acuteness of the topic under consideration or by the participation of definite personalities in resonant events. The natural information flows evidence public concern with a particular issue. The Attack Index graph demonstrates certain irregular (artificial) deviations from the Gausses Curve for the Roshen search request on 7 November 2019.

A detailed analysis of messages for 7 November 2019 proved that an artificial rise in the information wave was due to the story about P. Poroshenko's intention to register Roshen Corporation with his son. Since the Russian-speaking Internet audience is thirsty for the news about Ukrainian outstanding and influential statesmen and politicians, the news post, being scandalous enough, appeared among the top shares list.

Nonetheless, the Attack Index spotted 26 May 2020 as a probable information attack date. That day, the publication saying that the Russian confectionery factory "Rot Front" intended to file a lawsuit to prohibit the use of Romashka sweets wrapping by Roshen Corporation got 120 replications. The message originated from the Federal News Agency. The Attack Index also traced web interconnections between replica senders. In the majority of cases the electronic medium "New Time", often termed as pro-Russian, turned out to be an original news generator.

So, the Attack Index's reputational audit, run for Roshen corporation, will help media specialists to elaborate the most effective strategies for the company's commercial, PR, and image improvement. According to the students' observations, the corporation's faults are constant mentions linking to P. Poroshenko and his political tack. Such connections influence the company unfavorably and evoke a heterogeneous public response. That is why Russian and pro-Russian media promptly replicate the information concerning the Poroshenko-related company. Besides, the lawsuit for the sweets wrapping design may stand for copyright violation and illegal revenues. Thus, political neutrality and various promotional marketing techniques are essential in establishing the enterprise's probity.

After practice sessions the third- and fifth-year students completed a questionnaire to give their feedback as to their intentions to use the targeted web-services in the future (Table 4). As can be seen from the obtained results, the students are inclined to use the tools, as they secure high efficacy of data processing, especially concerning the temporal and quantitative expansion of information streams, both natural and artificial. 
Table 4

\section{Respondents' answers to the question "Do you find the targeted web-services like InfoStream and Attack Index helpful for your further professional career?"}

\begin{tabular}{|l|c|}
\hline \multicolumn{1}{|c|}{ Answer options } & Percentage of respondents \\
\hline Yes & $75 \%$ \\
\hline No & $10 \%$ \\
\hline Not sure & $15 \%$ \\
\hline
\end{tabular}

\section{CONCLUSIONS AND PROSPECTS FOR FURTHER RESEARCH}

Nowadays, at the time of ongoing hybrid wars, separatist and propaganda media must be under the state's control to withstand aggression and probable threats, in the information environment in particular. Meanwhile, manipulative technologies are constantly updating. That is why prospective journalists are to be able to critically assess information space. A topical issue in media education is elaborating youth-oriented interactive innovative technologies. The investigation findings ascertain that up-to-date web-services and factchecking applications can naturally be incorporated into the university curricula both for junior and senior students.

Because of the specific features of the information war in Ukraine, we designed a browser application to detect separatist/propaganda content. The practical testing of the tool proved its expedience and provided grounds for introducing the system into the educational process. The application turned out to be very advantageous in junior students' practical training. Thus, innovative teaching techniques are indispensable in the course of fostering professional competencies with future media specialists.

The targeted web-services (InfoStream and Attack Index) were attested by senior students at the practice sessions via formal discussions and a case-study analysis supervised by university instructors. We developed an algorithm for the tools' multi-purposeful usage. It contains all the stages of the analytical work, which can be automatized: content-analysis of the informational environment, identification of the most important news for a specific period and their ranking, formulation of the keywords on this basis, construction and decoding of graphs, reading and explaining extended information to graphs, conclusions on a specific communication case, recommendations for potential customers based on information processed through web services.

The services can effectively be resorted to in journalists' professional careers as well as in marketing and PR strategies. On mastering the basic skills in running such services and conducting a wavelet analysis, media workers can make active use of automated media monitoring systems for professional and research purposes. Thus, university practice sessions aiming at the development of such skills look promising for would-be media specialists. The conducted questionnaire serves as another proof that university educational programs will benefit from the incorporation of the examined applications and web-services into professional journalists' training.

\section{REFERENCES (TRANSLATED AND TRANSLITERATED)}

[1] J. Kahne, N.-J. Lee, and J. Feezell, "Digital Media Literacy Education and Online Civic and Political Participation", International Journal of Communication, 2012. [Online]. Available: https://ijoc.org/index.php/ijoc/article/view/999/675, Accessed: Dec. 10, 2020. (in English) 
[2] T. Valtonen, M. Tedre, K. Mäkitalo, and H. Vartiainen, "Media Literacy Education in the Age of Machine Learning", Journal of Media Literacy Education, $2019 . \quad$ [Online]. Available: https://digitalcommons.uri.edu/jmle/vol11/iss2/2/, Accessed: Dec. 10, 2020. (in English)

[3] T. Cherner and K. Curry, "Preparing Pre-Service Teachers to Teach Media Literacy: A Response to «Fake News»", Journal of Media Literacy Education, $2019 . \quad$ [Online]. Available: https://digitalcommons.uri.edu/jmle/vol11/iss1/1/, Accessed: Dec. 10, 2020. (in English)

[4] H. Schmidt, "Media Literacy Education from Kindergarten to College: A Comparison of How Media Literacy Is Addressed across the Educational System", Journal of Media Literacy Education, 2013. [Online]. Available: https://digitalcommons.uri.edu/jmle/vol5/iss1/3/, Accessed: Dec. 10, 2020. (in English)

[5] E. Schilder, B. Lockee, and P. Saxon, "The Challenges of Assessing Media Literacy Education", Journal of Media Literacy Education, 2016. [Online]. Available: https://digitalcommons.uri.edu/jmle/vol8/iss1/3/, Accessed: Dec. 10, 2020. (in English)

[6] P. Rasi, H. Vuojärvi, and H. Ruokamo, "Media Literacy Education for All Ages", Journal of Media Literacy Education, 2019. [Online]. Available: https://digitalcommons.uri.edu/jmle/vol11/iss2/1/, Accessed: Dec. 10, 2020. (in English)

[7] V. Rizun, "Methodology of identification and research of mass communication impact", Bulletin of Taras Shevchenko National University of Kyiv. Journalism series, vol. 20, pp. 42-57, 2013. (in Ukrainian)

[8] A. Begalinov, M. Ashilova, and K. Begalinova, "Cinema as the Platonic Cave: French Thinkers' Views on Media Education | Rupkatha Journal on Interdisciplinary Studies in Humanities”, Rupkatha.com, 2020. [Online]. Available: http://rupkatha.com/v10n214/. Accessed: Dec. 10, 2020. (in English)

[9] L. Naidonova, "School media workshop: motivational modules of media education for teenagers", Social pedagogue, vol. 10(34), pp. 347-352, 2009. (in Ukrainian)

[10] S. Matveeva, N. Akatova, Y. Shcherbakov, and N. Filinova, "Digitalization of Higher Education and Professional Development of Educators: Technologies and New Opportunities", Amazonia Investiga, vol. 9, no. 29, pp. $2020 . \quad 77-86, \quad$ Available: https://amazoniainvestiga.info/index.php/amazonia/article/view/1370/1223. Accessed: Dec. 10, 2020. (in English)

[11] O. Konevshchynska, "Development of media education and media culture under the conditions of the modern information society", Information Technologies and Learning Tools, vol. 54, no. 4, pp. 32-41, 2016. Available: https://journal.iitta.gov.ua/index.php/itlt/article/view/1481. Accessed: Dec. 10, 2020. (in Ukrainian)

[12] Y. Klyuev and V. Poznin, "Teaching Future Journalists Media Research Methodology Using Digital Technologies", Media Education, vol. $\quad 59(2)$, pp. 278-285, 2019. Available: http://ejournal53.com/journals_n/1558082359.pdf. Accessed: Dec. 10, 2020. (in English)

[13] S. Fiialka, "Hate speech on the pages of pro-Russian Internet media in social networks", Information society, vol. 24, pp. 14-21, 2017. Available: http://nbuv.gov.ua/UJRN/is_2016_24_4. Accessed: Dec. 10, 2020. (in Ukrainian)

[14] S. Fiialka, "Technical university students'media literacy in social networks", Media Education, vol. 4, pp. 7-13, 2017. Available: https://cyberleninka.ru/article/n/technical-university-students-media-literacy-insocial-networks. Accessed: Dec. 10, 2020. (in English)

[15] O. Husak and S. Fiialka, "Social media influence on public opinion and youth behavior", in Development trends in pedagogical and psychological sciences: the experience of countries of Eastern Europe and prospects of Ukraine, Riga: Baltija Publishing, 2018, pp. 31-52. Available: http://www.baltijapublishing.lv/download/pedpsy-science/pedpsy-science-2.pdf. Accessed: Dec. 10, 2020. (in English)

[16] T. Fisenko, "Instrumentary of political web-communications as a complex of media studies in political consulting", Humanities science current issues: Interuniversity collection of Drohobych Ivan Franko State Pedagogical University Young Scientists Research Papers, vol. 18, pp. 171-183, 2018.doi: https://doi.org/10.24919/2308-4863.18/18.168231. (in Ukrainian)

[17] L. Smola, A. Lytvyn, E. Mahda, and T. Fisenko, Political counseling as a phenomenon of mass communications. Kharkiv: Fact, 2017. (in Ukrainian)

[18] "List of sites containing information prohibited for dissemination by Ukrainian law", Ministry of Information Policy of Ukraine, 2019. [Online]. Available: http://mip.gov.ua/en/documents/116.html. Accessed: Dec. 10, 2020. (in Ukrainian)

[19] G. Pryshchepa, “«Hate speech» as a linguistic marker of a hybrid war”, Psycholinguistics, vol. 22(2), pp. 98-112, 2017. Available: https://psycholing-journal.com/index.php/journal/article/view/35/24. Accessed: Dec. 10, 2020. (in Ukrainian)

[20] V. Horbulin, O. Dodonov and D. Lande, Information operations and security of society: threats, counteraction, modeling. Kyiv: Intertekhnolohiia, 2009. (in Ukrainian) 
[21] T. Lindeberg, "Image matching using generalized scale-space interest points", Journal of Mathematical Imaging and Vision, vol. 52, no. 1, pp. 3-36, 2014. Available: https://www.researchgate.net/publication/236895491_Image_Matching_Using_Generalized_ScaleSpace_Interest_Points. Accessed: Dec. 10, 2020. (in English)

Text of the article was accepted by Editorial Team 16.12..2020

\title{
ВИКОРИСТАННЯ ВЕБСЕРВІСІВ ТА ДОДАТКІВ ДЛЯ ФОРМУВАННЯ МЕДІАГРАМОТНОСТІ МАЙБУТНІХ ЖУРНАЛІСТІВ
}

\author{
Фісенко Тетяна Вікторівна \\ кандидат наук із соціальних комунікацій, доцентка кафедри видавничої справи та редагування \\ Національний технічний університет України "Київський політехнічний інститут імені Ігоря \\ Сікорського", м. Київ, Україна \\ tfisenko@gmail.com \\ Гусак Ольвія Олександрівна \\ кандидат наук із соціальних комунікацій, доцентка кафедри видавничої справи та редагування \\ Національний технічний університет України "Київський політехнічний інститут імені Ігоря \\ Сікорського", м. Київ, Україна \\ olviya.g@gmail.com
}

\section{Тріщук Ольга Володимирівна}

професор, доктор наук із соціальних комунікацій, професорка кафедри видавничої справи та редагування Національний технічний університет України "Київський політехнічний інститут імені Ігоря

Сікорського", м. Київ, Україна

triov@ukr.net

\begin{abstract}
Анотація. У статті розглядаються як функціональні можливості наявних додатків, які доцільно використовувати в освітніх програмах 3 журналістики для формування медіаграмотності у студентів молодших курсів (а саме першокурсників та другокурсників), так і розробка додатку AntiSepar для браузера Chrome, що пройшов апробацію серед студентів спеціальності “Журналістика". Описано передумови створення технічного завдання для додатка, які було реалізовано в межах прикладної науково-дослідної роботи «Інструменти асиметричної відповіді на гібридну агресію в гуманітарній сфері», що проводилась на базі кафедри видавничої справи та редагування (Видавничо-поліграфічного інституту) Національного технічного університету України "Київський політехнічний інститут імені Ігоря Сікорського”. Результати анкетування, проведеного серед студентів (анкета була заповнена 100 респондентами) підтвердили ефективність створеного додатка, який може бути корисним інструментом для аналізу медіаконтенту різної тематики.

Крім того, під час проведення дистанційних практичних робіт та дискусій з профільних дисциплін для студентів старших курсів спеціальності «Журналістика» було запропоновано більш досконалий алгоритм опрацювання інформації з використанням автоматизованих систем для здійснення вейвлет-аналізу. Для опрацювання основних схем обробки інформації за допомогою сервісів InfoStream та Attack Index було проаналізовано кілька медіакейсів. Друга частина дослідження містить результати опитування, проведеного серед студентів, які отримують ступінь магістра (64 студенти).

У результаті дослідження авторами було зроблено висновки, що застосування цих інструментів дозволяє медіафахівцям простіше та ефективніше відстежувати потоки новин та їх взаємозв'язкок, а також джерела розповсюдження інформації.
\end{abstract}

Ключові слова: вебсервіс; журналістика; медіаграмотність; мобільний додаток; освіта. 


\title{
ИСПОЛЬЗОВАНИЕ ВЕБ-СЕРВИСОВ И ПРИЛОЖЕНИЙ ДЛЯ ФОРМИРОВАНИЯ МЕДИАГРАМОТНОСТИ БУДУЩИХ ЖУРНАЛИСТОВ
}

\author{
Фисенко Татьяна Викторовна \\ кандидат наук по социальным коммуникациям, доцент кафедры издательского дела и редактирования \\ Национальный технический университет Украины “Киевский политехнический институт имени Игоря \\ Сикорского”, г. Киев, Украина \\ tfisenko@gmail.com
}

Гусак Ольвия Александровна

кандидат наук по социальным коммуникациям, доцент кафедры издательского дела и редактирования Национальный технический университет Украины “Киевский политехнический институт имени Игоря Сикорского”, г. Киев, Украина olviya.g@gmail.com

\author{
Трищук Ольга Владимировна \\ профессор, \\ доктор наук по социальным коммуникациям, профессор кафедры издательского дела и редактирования \\ Национальный технический университет Украины “Киевский политехнический институт имени Игоря \\ Сикорского", г. Киев, Украина. \\ triov@ukr.net
}

\begin{abstract}
Аннотация. В статье рассматриваются как функциональные возможности имеющихся приложений, которые целесообразно использовать в образовательных программах по журналистике для формирования медиаграмотности у студентов младших курсов (а именно первокурсников и второкурсников), так и разработка приложения AntiSepar для браузера Chrome, которое прошло апробацию среди студентов специальности “Журналистика". Описаны предпосылки создания технического задания для приложения, которое было реализовано в рамках прикладной научно-исследовательской работы “Инструменты асимметричного ответа на гибридную агрессию в гуманитарной сфере”, проводимой на базе кафедры издательского дела и редактирования (Издательско-полиграфического института) Национального технического университета Украины "Киевский политехнический институт имени Игоря Сикорского”. Результаты анкетирования, проведенного среди студентов (анкета была заполнена 100 респондентами), подтвердили эффективность созданного приложения, которое может быть полезным инструментом для анализа медиаконтента различной тематики.

Кроме того, во время проведения дистанционных практических работ и дискуссий по профильным дисциплинам для студентов старших курсов специальности "Журналистика" было предложено более совершенный алгоритм обработки информации с использованием автоматизированных систем для осуществления вейвлет-анализа. Для проработки основных схем обработки информации с помощью сервисов InfoStream и Attack Index были проанализированы несколько медиакейсов. Вторая часть исследования содержит результаты опроса, проведенного среди студентов, получающих степень магистра (64 студента).

В результате исследования авторами были сделаны выводы, что применение этих инструментов позволяет медиаспециалистам проще и эффективнее отслеживать потоки новостей и их взаимосвязь, а также источники распространения информации.
\end{abstract}

Ключевые слова: веб-сервис; журналистика; медиаграмотность; мобильное приложение; образование.

\section{$(\mathrm{Cc})$ BY-NC-SA}

This work is licensed under Creative Commons Attribution-NonCommercial-ShareAlike 4.0 International License. 